\title{
Recenzja książki: Anna Krajewska, Współdziałanie dydaktyczne nauczycieli akademickich i studentów a jakość kształcenia na przykładzie studiów pedagogicznych, Białystok 2016, sS. 433
}

Wydanie recenzowanej książki Anny Krajewskiej poprzedzone było publikacjami takich artykułów autorki, jak Przedmiot i treści współdziałania dydaktycznego nauczycieli i studentów w fazach procesu kształcenia w ocenie jego uczestników (2014a), Teoria współdziałania $w$ uczeniu się - podstawowe założenia, wyniki badań i możliwości zastosowania w praktyce (2014b), czy też Współdziałanie dydaktyczne osób w preparacji procesu kształcenia w ocenie nauczycieli i studentów oraz jego uwarunkowania (2014c). Książka scala zatem zainteresowania i dorobek autorki wokół współdziałania dydaktycznego podmiotów procesu kształcenia i związanej z nim jakości kształcenia. Spoiwem łączącym te dwa składniki są podmioty procesu dydaktycznego w uczelni, czyli nauczyciele i studenci. Współdziałanie nauczycieli ze studentami i jakość kształcenia zostały w książce bardzo szczegółowo zaprezentowane w szesnastu rozdziałach.

Pierwszy rozdział A. Krajewska poświęca opisowi kontekstów funkcjonowania szkolnictwa wyższego (filozoficzny, społeczno-ekonomiczny, edukacyjny). Wartością tej części monografii jest wskazanie przemian w filozofii, teorii, a także w praktyce edukacyjnej, będących wyrazem potrzeb i oczekiwań społeczeństwa wobec edukacji. Istotną część tego rozdziału stanowi wskazanie źródeł przemian w podmiotowych elementach systemu kształcenia. Autorka przytoczyła koncepcje i teorie odnoszące się m.in. do współdziałania nauczycieli i studentów czy też współzależności tych podmiotów procesu kształcenia. Uważam, że cennym postępowaniem w tej części książki jest wyodrębnienie wniosków po każdorazowym omówieniu dominujących teorii i przedstawienie wskazań dotyczących podmiotów procesu kształcenia, a mających znaczenie dla podejmowanego współdziałania, jak i dla podnoszenia jakości działań dydaktycznych. Wnioski i propozycje zmian we współdziałaniu dydaktycznym, wynikające z analizy wyników badań, autorka zawarła w części empirycznej.

Dwie części książki, teoretyczna i empiryczna, uzupełniają się, tworząc spójną całość. W części teoretycznej A. Krajewska wskazała nie tylko społeczny kontekst zmian mający wpływ na szkolnictwo wyższe, ale także wprowadziła w sposób przekonujący własne usta- 
lenia terminologiczne oraz przyjęte założenia dotyczące kluczowych elementów przeprowadzonego procesu badawczego, a niezbędne dla rozumienia przez czytelników wywodu teoretyczno-badawczego. Autorka określiła, jakie przyjmuje rozumienie działania (s. 94) i współdziałania dydaktycznego (s. 114, 131), a także jakości kształcenia (s. 82-83). Wskazała także obszernie strukturę i rodzaje wyróżnionych elementów w różnych dyscyplinach nauki, np. w filozofii, socjologii. Poprzedzając ustalenia terminologiczne, w czytelny sposób zaprezentowała bardzo szeroki przegląd literatury dotyczącej omawianych zagadnień.

Moim zdaniem bardzo interesujące jest - i warte byłoby osobnego, szerszego opracowania - odniesienie się przez autorkę do koncepcji kapitału ludzkiego i kapitału społecznego, do koncepcji doskonałości w rozwoju talentu, jak też koncepcji „nowej odpowiedzialności”. Warto podkreślić, że w każdej z tych koncepcji ważny jest cel, jakim jest „wzrost osobowy”. W przypadku kapitału istotne jest „pomnażanie”, czyli nieustający rozwój poprzez dostęp do kapitałów drugiego człowieka, dzięki podjęciu relacji np. nauczyciel-student, z uwzględnieniem wzajemnego współdziałania (Dudzikowa i in., 2011). Talenty tworzą możliwość „przyspieszonego rozwoju” (Dąbrowski, 1979, s. 71-72) osobowego dzięki uzdolnieniom i swobodnemu korzystaniu z posiadanych umiejętności. Warto wspomnieć też, że spotkanie m.in. z „(..) ludźmi może pomóc każdemu (...) odnaleźć swoje powołanie" (Gardner, 2002, s. 56).

Myślę, że duże zainteresowanie może wzbudzić zastosowana przez A. Krajewską metoda modelowania, dzięki której autorka przedstawiła fazy dydaktycznego współdziałania nauczycieli ze studentami w procesie kształcenia: fazę preparacji, fazę realizacji, jak też fazę kontroli i oceny (s. 16). Zaproponowany model systemu współdziałania dydaktycznego ukazuje złożoność tego systemu, ale także cykliczność faz w procesie kształcenia. Istotne wydaje się to, że przed każdym kolejnym cyklem istnieje możliwość ewaluacji i wprowadzania zmian w systemie współdziałania nauczycieli ze studentami.

Jak stwierdziła autorka, ważna jest taka realizacja procesu kształcenia, aby w każdej z faz uczestniczyli jednocześnie nauczyciele i studenci, a studenci czuli się współodpowiedzialni za realizację celów każdej z faz. A. Krajewska wskazała, że działania nauczycieli i studentów są świadome, jak też współzależne poprzez wspólne lub zgodne cele (s. 16). Dodałabym, że są także częścią podejmowanej przez nich relacji, której celem jest m.in. dążenie do rozwoju i samorozwoju uczestników relacji. W procesie dążenia do rozwoju i samorozwoju znaczenie ma, z jednej strony, towarzyszenie studentowi na drodze jego poszukiwań (Olbrycht, 1987, s. 79), a z drugiej strony, wykorzystanie doświadczenia podążania wspólną drogą do poszerzania własnej świadomości pedagogicznej przez nauczyciela (Andrzejewska, 2016).

W dobie łatwej wymiany informacji na odległość (np. poprzez Internet) nadal wskazuje się na wagę relacji bezpośredniej i - co się z tym wiąże - bezpośredniego współdziałania. Współdziałanie jest jednym $\mathrm{z}$ istotnych elementów relacji nauczyciel-student, mimo że wskazuje się na możliwość wzajemnego negatywnego oddziaływania - obosieczność pozycji mistrza. Podkreślić jednak należy, że istotna i przeważająca jest także możliwość pozytywnego oddziaływania, ponieważ ludzie potrzebują nauczycieli, mistrzów, opiekunów i przewodników życia. 
Trzeba tu podkreślić, że dogłębne rozpoznawanie elementów relacji, takich jak np. współdziałanie dydaktyczne nauczycieli i studentów, jest potrzebne, a nawet konieczne, dlatego dużą wagę mają zastosowane przez A. Krajewską badania diagnostyczne i wyjaśniające. Stosowane są w nich takie narzędzia i metody badawcze, jak np. obserwacja, wywiad lub ankieta czy analiza dokumentów, np. kart okresowych osiągnięć studenta. Ich skuteczność wzmacnia interdyscyplinarne spojrzenie poprzez pryzmat nie tylko pedagoga, ale także np. filozofa, co zastosowała autorka recenzowanej książki.

$\mathrm{W}$ jedenastu rozdziałach (V-XV) zaprezentowany został bardzo obszerny materiał empiryczny. A. Krajewska wykorzystała tutaj opracowany przez siebie model współdziałania dydaktycznego nauczycieli i studentów w procesie kształcenia. Model ten zawiera, poza fazami procesu kształcenia, również inne parametry warunkujące jakość kształcenia (cele, przedmioty, treści, metody, środki, formy organizacyjne, warunki wewnętrzne i zewnętrzne, rezultaty), a także, jak przyjęła autorka, cechy współdziałających podmiotów, takie jak odpowiedzialność nauczycieli i studentów, aktywność, samodzielność, poczucie podmiotowości studentów.

Moim zdaniem model ten można rozszerzyć o aktywność, samodzielność i podmiotowość nauczycieli, zwłaszcza że wśród zmiennych pośredniczących w grupie cech nauczycieli autorka wymienia staż pracy nauczyciela. Staż pracy nauczyciela jest także wskazany w jednej z hipotez, w której wieloletnie doświadczenie nauczyciela jest przykładem elementu różnicującego ocenę poziomu współdziałania dydaktycznego. Spowodowane jest to tym, że nauczyciel z krótszym stażem pracy może wykazywać mniejszą efektywność we współdziałaniu ze studentem niż nauczyciel z długim stażem pracy, może być także mniej samodzielny, np. przez mniejsze poczucie własnej podmiotowości w działaniu dydaktycznym.

W książce zostało podkreślone, że jakość kształcenia jest uwarunkowana zaawansowaniem współdziałania nauczycieli ze studentami. Współdziałanie owych podmiotów procesu kształcenia nie jest jednak wyizolowane ze świata zewnętrznego i nie jest zamknięte tylko w jednej jednostce dydaktycznej - w przeprowadzonych zajęciach wykładowych czy ćwiczeniowych. W tym miejscu warto wspomnieć o jednej z funkcji szkolnictwa wyższego: promocyjno-środowiskowej. Pokazuje ona, że poza współdziałaniem nauczycieli i studentów podczas zajęć ważne jest także ich współdziałanie ze środowiskiem społecznym (m.in. zawodowym). Owo współdziałanie daje szansę na zdobycie przez studentów nowych doświadczeń poprzez prezentację zdobytych umiejętności, a nauczycielom na zdobycie nowych doświadczeń i nieskostnienie w rutynowych działaniach (Jankowski, 2012, s. 9-11).

Podsumowując, pragnę podkreślić, że istotnym wkładem autorki jest m.in. zaprezentowanie wyników badań zarówno według kryteriów ilościowych, jak i jakościowych. Warto wskazać jednak, że niektórzy badacze uznają i preferują łączenie podejścia ilościowego z jakościowym. Ta część badaczy, podobnie jak autorka książki, uważa, że łączenie metod daje szerszy ogląd zjawiska (Andrzejewska, 2016). Inni jednak wolą podział na podejście ilościowe i podejście jakościowe. Osobiście preferuję podporządkowanie całego procesu badawczego podejściu jakościowemu, które daje większą swobodę badaczowi, ponieważ „proces badawczy rozpoczyna się wprawdzie postawieniem problemów, te jednak w przebiegu pro- 
cesu badań stale podlegają modyfikacji i rozszerzeniom” (Krüger, 2007, s. 159-161). Szczególnie interesująca zatem jest dla mnie możliwość zapoznania się z przedstawionymi przez autorkę wynikami analizy jakościowej.

A. Krajewska ukazała działania oraz konteksty współdziałania nauczycieli i studentów mających znaczenie dla podnoszenia jakości kształcenia. Autorka we wnioskach wskazała, że „studenci niżej niż nauczyciele ocenili poziom współdziałania dydaktycznego w prawie wszystkich elementach systemu w fazach procesu kształcenia” (s. 191). Można zatem zauważyć, że nauczyciele, poznając opinię studentów, mogą bardziej krytycznie spojrzeć na dotychczasową współpracę i podjąć głębszą refleksję nad swoimi działaniami jako nauczyciela $\mathrm{w}$ relacji ze studentem.

Nauczyciele i studenci mogą postrzegać i oceniać współdziałanie jako źródło możliwości w procesie wzajemnego rozwoju. W procesie tym istotne znaczenie ma świadomość istnienia barier i umiejętność ich pokonywania (Andrzejewska, 2016) w przebiegu relacji nauczyciel-student. A. Krajewska w wynikach swoich badań przedstawiła opinie obydwu podmiotów owej relacji dotyczące korzyści nauczycieli i studentów, wynikające ze współdziałania w fazach procesu kształcenia, takie jak „wyższy poziom wzajemnego zaangażowania, lepsza komunikacja, wyższy poziom zadowolenia, większa satysfakcja i korzyści dla obu stron" (s. 338). Wśród uwarunkowań sprzyjających i utrudniających współdziałanie dydaktyczne autorka wymienia m.in. cechy osobowości. W moich badaniach cechy osobowości nauczycieli i studentów również wskazywane były jako sprzyjające lub utrudniające wzajemną relację.

Wartość poznawcza wyników badań przeprowadzonych przez A. Krajewską jest wysoka. Warto zatem zapoznać się z wynikami badań oraz wnioskami, które wskazuje jako istotne dla praktyki we wzajemnym współdziałaniu, a dodam, że i we wzajemnej relacji nauczyciel-student. Autorka nie ograniczyła swoich wskazań tylko do nauczycieli i studentów, ale przejrzyście zaprezentowała również ważne implikacje zarówno dla władz uczelni prowadzących kształcenie na kierunku pedagogika, jak i implikacje dla komisji zajmujących się jakością kształcenia.

Badania swoje autorka oparła na bogatej analizie literatury dotyczącej zarówno podstaw teoretycznych, jak i warsztatu badawczego. Przypuszczam, że wyjątkowo ciekawe i nowatorskie wyniki tych badań są efektem m.in. tej dogłębnej analizy. Wyniki badań są także doskonałym źródłem inspiracji dla kolejnych badaczy. Praca stanowi spójną całość teoretyczno-badawczą. W książce wskazana została złożoność systemu współdziałania nauczycieli i studentów w procesie kształcenia (s. 165), a także konstatacja, że przebieg współdziałania - a dodam, że i przebieg relacji - nauczycieli i studentów uwarunkowany jest wieloma czynnikami. Jednym z najważniejszych są sami uczestnicy owego współdziałania, jak i relacji, ponieważ ich działania, ich odpowiedzialność, aktywność, samodzielność i poczucie podmiotowości wpływa na pozostałe elementy współdziałania i relacji, takie jak np. ustalenie celu współdziałania, wybór metod pracy czy środków.

Książka dzięki interdyscyplinarnemu podejściu do podejmowanych zagadnień wnosi wiele nowych ustaleń i stanowi istotne uzupełnienie literatury poświęconej współdzia- 
łaniu nauczycieli i studentów. Zastosowanie natomiast podejścia ilościowo-jakościowego zaspokaja oczekiwania zwolenników zarówno łączenia metod, jak i zwolenników metod ilościowych, ale też, jak w moim przypadku, zwolenników stosowania metod jakościowych. W ujęciu wskazanym przez autorkę badania ilościowe i badania jakościowe są komplementarne. Warto podkreślić na zakończenie, że nie tylko wyniki badań A. Krajewskiej przedstawione w książce, ale także bardzo bogaty przegląd literatury, którą przytacza autorka, może być źródłem wiedzy dla innych badaczy zajmujących się zagadnieniami dotyczącymi szkolnictwa wyższego.

Podsumowując, pragnę przytoczyć słowa Andrzeja Góralskiego (2014) dotyczące m.in. znaczenia odkrywania i poszukiwania kontekstów współdziałania „(...) pożyteczna sugestia: Polacy, mistrzowie dokonań indywidualnych, gruntujcie i rozwijajcie umiejętności współpracy poznawczej i realizacyjnej, pogłębiajcie wiedzę o sposobach współdziałania sprawnego, innowacyjnego i zgodnego z wymogami współczesności” (s. 331). To właśnie o współdziałaniu dydaktycznym nauczycieli ze studentami zgodnym z wymogami współczesności napisała A. Krajewska na podstawie literatury, a także badań własnych.

\section{Bibliografia}

Andrzejewska, T.J. (2016). Relacja mistrz-uczeń w edukacji akademickiej. Szczecin [praca doktorska napisana pod kierunkiem naukowym Anny Murawskiej].

Bauman, T. (2010). Poznawczy status danych jakościowych. W: J. Piekarski, D. Urbaniak-Zając, K.J. Szmidt (red.), Metodologiczne problemy tworzenia wiedzy w pedagogice. Oblicza akademickiej praktyki (s. 91-105). Kraków: Oficyna Wydawnicza Impuls.

Dąbrowski, K. (1979). Dezintegracja pozytywna. Warszawa: Państwowy Instytut Wydawniczy.

Dudzikowa M., Jaskulska, S., Wawrzyniak-Beszterda, R., Bochno, E. (red.). (2011). Kapitał społeczny w szkołach różnego szczebla. Diagnoza i uwarunkowania, t. II. Kraków: Oficyna Wydawnicza Impuls.

Gardner, H. (2002). Inteligencje wielorakie. Teoria w praktyce, przeł. A. Jankowski. Poznań. Media Rodzina.

Góralski, A. (2014). Ścieżki twórczości, próby, dokonania, syntezy, t. II. Warszawa: Wydawnictwo Akademii Pedagogiki Specjalnej.

Jankowski, W.B. (2012). Wprowadzenie. W: W. Jankowski (red.), Raport o stanie szkolnictwa muzycznego I stopnia, Diagnozy, problemy, wnioski modelowe (s. 7-18). Warszawa: Instytut Muzyki i Tańca.

Krajewska, A. (2014a). Przedmiot i treści współdziałania dydaktycznego nauczycieli i studentów w fazach procesu kształcenia w ocenie jego uczestników. W: J. Grzesiak (red.), Ewaluacja $i$ innowacje w edukacji. Ewaluacja poprawy jakości kształcenia (s. 363-374). Kalisz-Konin: UAM Poznań, PWSZ Konin. 
Krajewska, A. (2014b). Teoria współdziałania w uczeniu się - podstawowe założenia, wyniki badań i możliwości zastosowania w praktyce. W: M. Kowalczuk-Walędziak, A. Korzeniecka-Bondar, K. Bocheńska-Włostowska (red.), Twórcze wiązanie teorii i praktyki pedagogicznej - możliwości, wyzwania, inspiracje (s. 60-80). Kraków: Oficyna Wydawnicza „Impuls”.

Krajewska, A. (2014c). Współdziałanie dydaktyczne osób w preparacji procesu kształcenia w ocenie nauczycieli i studentów oraz jego uwarunkowania. W: A. Karpińska W. Wróblewska (red.), Dydaktyka akademicka - wybrane obszary badawcze (s. 108-121). Warszawa: Wydawnictwo Akademickie „Żak”.

Krajewska, A. (2016). Współdziałanie dydaktyczne nauczycieli akademickich i studentów a jakość kształcenia na przykładzie studiów pedagogicznych. Białystok: Trans Humana.

Krüger, H.H. (2007). Metody badań w pedagogice, przeł. D. Sztobryn. Gdańsk: Gdańskie Wydawnictwo Psychologiczne.

Olbrycht, K. (1987). Sztuka a działania pedagogów. Katowice: Uniwersytet Śląski.

Witkowski, L. (2007). Między pedagogiką, filozofią i kulturą. Studia, eseje, szkice. Warszawa: Instytut Badań Edukacyjnych. 